ARTICLE

DOI: $10.1057 /$ s41599-018-0193-6

\title{
Look, a human being! Anthropomorphic solipsism in postsecular thought
}

Noëlle Vahanian ${ }^{1}$

\begin{abstract}
Adding a woman's voice to an edited volume, or a person of color on an academic panel, or an ecumenical, universalist message of welcome under a church flagthese may be well intentioned gestures of inclusion, but, even as an unintended result, minority discourses either stand on the margins, as the 'other,' or they morph and disappear into the dominant discourse. What is needed instead is a change of 'being.' Whatever we call the philosophy of religion, it owes its conception to the European Enlightenment, and the latter, its understanding of the modern subject to Christian imperialism and the colonial enterprise. How can it ever become an inclusive field? This paper reflects on the promise of inclusion of postsecular theological discourses within the Continental philosophy of religion. Can such discourses, coming on the heels of the death of God and the postmodern death of universals, overcome their patriarchal, colonial, and racist cultural archive? Such a possibility glimpses a future worth pursuing. To answer the question, this paper plays on the intersectionality of the human being as such-an imagined abstract condition of possibility of our existence-and human facticity, the embodied lived experience that is historically conditioned, culturally determined, gendered and racialized as we know it today-identities expressing or underwriting white privilege, the economic exploitation of the global south, or hegemonic Western institutions of knowledge and power. The paper analyzes key aspects of well-known postsecular theological discourses (Caputo, Vattimo, Taylor, Levinas) through the intersectional lens of feminist, race, postcolonial, and decolonial critiques (Schutte, Du Bois, Carter, Dussel, Mignolo). Error is human, but today's sexism, racism, or economic oppression suggest it isn't human errors we ought to correct so much as our erroneous understanding of what we call a human being. A materialist conception of being (Malabou) and a theology whose God is in and of language open the way to engage the complicity of the philosophy of religion with the dominant and hegemonic ideologies that underwrite, besides the field, today's world order.
\end{abstract}

\footnotetext{
${ }^{1}$ Lebanon Valley College, 101 North College AveAnnville 17003 PA, United States. Correspondence and requests for materials should be addressed to N.V. (email: vahanian@lvc.edu)
} 


\section{Introduction}

begin with a problem. But so often, as I will suggest, this problem has appeared in the guise of another. Here are some iterations: the Negro problem; the Indian problem; the Jew problem; the woman problem; the question of Being problem; the God problem. A first point is thus that, at root, these so-called problems (and my list is certainly not exhaustive) are all expressions of the human problem when the human being does not see herself as the problem; when man does not see himself as the source of the woman problem; when White man does not see himself as the source of the Negro problem; when European man does not see himself as the source of the Latin American problem. Or, in short, when the human being thinks he knows himself. This problem, I contend, is the task of the Continental philosophy of religion, if it is truly to have a future that is not just for its tunnel-vision of itself. But, to contend with this problem, however, means to change the human being at the heart of the problem.

For this suggestions to stand, I will ask the reader to consider as a hypothesis an inextricable, though historical (conditional), collusion of our anthropomorphic perspectivalism and our Eurocentric cultural inheritance. ${ }^{\text {Th }}$ This word, collusion, may not be the most apt for the link I want to underscore, but I mean for it to call attention to a kind of duplicity that might very well operate in denial. Our ignorance of this link makes us all the more complicit in it. In the United States, for instance, the concept of white privilege expresses an important aspect of this collusion. But our calling it out, just as our calling out of white privilege, does not do away with the problem. Rather, its inextricability means that there is no easy way out of the problem, just as there is no easy way out of this world for another. Instead, therefore, we might venture a better way in.

By a 'better way in,' I echo what I have proposed elsewhere, which, for me, is the only viable option for theology today, namely the way of a secular theology of language. ${ }^{2}$ Wait! Isn't theology what has been used to legitimate a racialized and patriarchal hierarchy of beings? One can easily point to the papal bulls that from the Renaissance on have led to the unequal economic partitioning of the globe through the Doctrine of Discovery. Or, one could also mention the gendercidal witch hunts carried out against so many women whose status as such was perceived as a threat to the inherent sexism of a patriarchal Christian order. While we are far away from this old state of affairs, the same old values still prevail. One just has to consider the most recent US elections in which a misogynous white male was elected. How then could a theology pretend to offer a solution to this bankrupt world-order of things?

But precisely, doing away with theology has not done and does not do away with such poor values even if it does lead us to the death of God, to the postmodern condition of knowledge and to the linguistic turn. My position is simply that one cannot strip oneself of one's cultural inheritance; such is called facticity. But one can rebel against the status quo and subvert one's inheritance. A secular theology of language is such an attempt. It is a theology for this world, without transcendence or omnipotent, metaphysical God, and, in this sense, it is a secular theology. It is an insurrectionist theology, a Rebellious No! to flat ordinariness, to normative subjectivities, and to the capitulation of desire to a capitalistic world-order predicated on the expendability of life, especially along gender, racial and cultural lines. ${ }^{3}$ At the same time, this is also a theology whose faith is its absurdism, its recalcitrance to the trope of hope, its iconoclastic suspicion of the big ideas that it cannot live without-its own included. One's cultural inheritance is also one's language, in a figurative sense. It is the language that inhabits each and one of us and through which we come to identify ourselves. We are 'language' made flesh and, for this secular theology, therefore, God is a word in the dictionary, a word that stands for the figure that interpellates a kind of subject who is always beyond herself or in spite of herself, or undoing herself.

In sum, then, and to go back to the problem at hand that so often appears in the guise of another, I propose that a secular theology of language is a way to rebel from within hegemony. At the same time, I must make clear that I do not intend to conflate the cultural, social, political or historical struggles of various peoples or genders and from different historical periods by reducing these struggles to a single problem. But what I want to emphasize is how this misdiagnosis of a general condition (human condition) for a particular problem (woman, Jew, etc.) betrays a certain misplaced concreteness in the concept of the human being, so that this being, in its generality, is believed to be something else (riddle, enigma) besides some abstraction for taxonomical or rhetorical and political purposes. For instance, in the names of human Christianity, crusaders killed infants, conquistadores claimed indentured servants, missionaries worked Indians to death; in the name of human equality, women and slaves were denied a place in the polity; in the name of human civilization, a genocidal Indian Removal act deprived a people of its way of life; in the name of a superior human race, Nazis exterminated six million Jews and any life deemed unworthy of living and so forth. This list may seem erratic, but I only want to emphasize how the human, certain conceptions of the human, and the oft repeated, unchecked assumptions about this human are at the heart of the many iterations of the problem of the other-other race, gender, peoples, cultures and civilizations. Just as Simone de Beauvoir affirmed the phenomenological platitude that consciousness is always consciousness of the other only to underscore the sexism at the heart of humanist thought (such that woman is denied the subject position, is always the other to man), I am here underscoring this subject/human position and its excesses.

Here, then, is an argument for a thinking that is not somatophobic, but that understands its complicity with life-real incarnated, raced, sexed, and messy gendered life. This feminist move is well known: redress the necrophilia of patriarchal, universalizing discourses with life affirming, difference embracing, body-oriented redeeming discourses, in the vein of a Grace Jantzen, or the genealogy of the philosopher who refused the label such as Hannah Arendt, or the white ink style of an Hélène Cixous, or the politics of a Gayatri Spivak dubbed strategic essentialism as developed by a Luce Irigaray. But for my purposes here, I/we must ask how the well-known and well-worn-though, to be clear, no less urgent-feminist script gets reiterated, if not altered and transformed, after the death of God and in the wake of the postmodern? Put otherwise, how has God returned in postsecular discourses? Weak being or not, the word God does have, a patriarchal, imperial-and we can add, a White and genocidal-archive.

By postsecular, I refer to largely philosophical or theological discourses that acknowledge the failure of the Enlightenment secularization thesis and that recognize that the Death of God is the apotheosis of this thesis according to which faith and reason stand opposed. ${ }^{4}$ By this reading, and to borrow the phrase from the titles of two of the most well-known books of their ilk and of their period, the death of God theologies of the 1960s were a time-bound movement that wrongly announced a 'post-Christian era' (Vahanian, 1961), or more generally, the inauguration of a truly 'secular city' (Cox, 1965). To borrow from John Caputo, the postsecular is born when we become more enlightened of these enlightened critiques of religion-and thus, the postsecular is not only after the death of God, but even more, is characterized by the death of the death of God. 
Consider, however, the critique lodged against John Caputo's theological reading of Jacques Derrida-namely, that a weak God as event in a world without pure universals lends credibility to more fundamentalist fideistic discourses that can dispense with the tribunal of reason. ${ }^{5}$ And so, who is to say that the Burka or the Niqab, or even the Hijab, are oppressive to all women just because veiling is perceived as oppressive to Westerners? Whose laws ought to prevail? I have in mind the August 2016 French highest administrative court ruling against banning burkinis on the grounds that such prohibition (which had been issued by several French towns) is discriminatory and Islamophobic. But even the postsecular thinker, Gianni Vattimo, suggests that, in a secular setting, the chador can only but manifest a strong reading of Islam, a 'kind of profession of fundamentalism' (Vattimo, 2002, pp. 101-102). Likewise, who is to say that God's love is not manifested through human suffering (the suffering of the poor, of the battered spouse, of the different one)? Put this way, the thought may seem farfetched, but, to give just one example, who isn't familiar with the oft repeated deprecatory justifications for keeping the minimum wage below a living wage and that, in a nutshell, trumpet that the poor deserve to be so? Could a weak God or a weak thought not be used to defend such positions? It is in this alternative sense that the postsecular might be seen as unwittingly eclipsing the other (viz.: the others, minorities, the marginalized, the foreigner, etc...) while maintaining and even while hoping and wishing for just the opposite. I, therefore, have in mind moments in my own theological work-call it secular or radical or materialist or insurrectionst-where I wonder whether the postsecular assumption of an overcoming of the religious/ secular binary might in fact be a real eclipse of sex, gender, and differences. Does it follow that once the bad metaphysics are overcome, so too are the dualistic binaries that privilege death and the beyond over life in its many and constant instantiations? It doesn't. The fact is that even as postsecularity can surely be understood as a response to secularism in its hidden colonial racialism, Christian universalism, and sexist humanism, when a postsecular theology is silent about the body this betrays a tunnel vision as opposed to a blind spot. This is what needs to be explored.

Perhaps one of the most engulfing ways to conceive of the problem (of how the problem is a problem, of whether or not the problem that is a problem can be posed as a single problem-as its own problem) is to engage the problem of the human as universal through at least three of its most salient critiques: the feminist critique, the race critique, and the decolonial critique. To the extent that the overcoming of the secular/religious binary can be genuine-not a return to triumphalist, exclusivist discourses giving legitimacy to status-quo politics and clash of civilization divisiveness, any legitimate postsecular thought will need to rethink its position with respect to its inherited and enduring structural sins. It will have to rethink its complicity with Western imperialism and global capitalism, a complicity that, and whether unintended or even imposed and denounced, cannot not be, other than in willful ignorance.

This is also why I suggest that that we must navigate the difficult terrain of tropes of hope and change, of resistance and resilience, from within complicity. Openly influenced by Catherine Malabou's materialism, I try to envision the possibility of real change-which does not require a savior-that real change is possible because we, ourselves, are complicit in our becoming if nothing more than human, then at the very least, a problem.

To this end, I will toy (without going into any real substantive depth) with the potential use or worth of a putative speculative realist approach to think differences and, borrowing the concept from Malabou, to make a changing difference (see Malabou, 2011). In other words, I consider whether such a transcendental metaphysics is helpful in thinking, beyond differences, how to effect change. The apriori appeal of speculative realism, in its Graham Harman version for instance, specifically as it is expounded in his essay, 'Objects and Orientalism,' is that the speculative realist might suggest that objects are always more than what subjective human perception makes of them, but, for all that (and beyond or independent of their being understood), they are still objects (Harman, 2014). Who is the human being to think that the perceived and perceptual limit of her world is the real limit of the world? Who is he to think that the empirical limit of his experiences are the limits for all experiences? The human is object, to be sure, who forgets that he is just an object among other objects. But, for the speculative realist, the essence of this object is some mysterious, yet very real, transcendent othertranscendent even to himself. And by that reasoning, whereof one cannot speak, thereof one must not be silent. One must dare to chart the unknown territory; risk going beyond the pedestrian; venture out of the solar orbit, and anchor for the surprise of wonder, when the other reveals itself like the apple falling on Newton's head, jolting him out of his anthropomorphic slumber. The appeal, in short, is that objects are exceeded by the sum of their knowable or known parts, and further, the claim is that this offers a way of out anthropocentric tunnel vision.

In the end, I want to emphasize that the aim of the secular theology I wish to affirm is to offer more than hope to come: to offer a way to envision real change from within the enigma of the human being, from whose borders none of us can totally escape, but in whose universal shoes none of us earth animals ever walk. ${ }^{6}$

\section{Part 1. Western, unitary subject/postcolonial, hybrid subjectivities}

Before such a way to envision real change within the enigma of the human being can be conceived, we must look at the challenges posed, not by the desire for inclusivity, but by the very nature of hegemony as it affects and is affected by those who stand outside of the major discourses. One of the graver issues, which goes to the heart of my attempt to envision change, is the real worry that assimilation into a dominant discourse and appropriation of minority discourses have found their way even where clear attempts have been made to promote diversity, such as in the academy. Social and linguistic constructivism, for instance, lead to a view of identity formation as a one-way street, so to speak: the other finds a place within the hegemony, is no longer other, and the hegemonic discourse does not fundamentally change, it appropriates or includes only to better subsume.

But what does such an analysis have to do with postsecular thought? One can make the case that such thought is made possible precisely as the academy opens up to theological thinking. In the fifties and sixties, in the United States, secular religion departments are created within the Humanities. Certainly, theological schools still exist, but this secular discipline means that Christian theology, too, is studied "objectively." For some, this opens the door to doing theology differently-in the spirit of death of God theologies, and eventually, it also leads to the possibility of secular theology. Regrettably, this has also meant that theology is often taboo in certain religious studies departments, with the assumption that the study of religion(s) is an objective science. Of course, the sixties is also the era of civil rights, women's liberation, and of the baby boom generation. It is when deconstruction takes the academy by storm, and here, in the US, well into the nineties. Some philosophy or history departments are impermeable to this revolution, and it is in or through English departments, sometimes religion departments, or through the creation of subaltern departments (women and gender studies, Africana studies, etc...) that postmodern and 
poststructural ideas find a haven. So where is the kind of postsecular thought that is not in the old school of theology and that is not a complete rejection or disavowal of the secularization thesis? It navigates the academy, sometimes it falls under what is now labeled in the United States Continental philosophy of religion, or in Europe, phenomenology of religion, or hermeneutic philosophy, even. Under such labels, however, even nondogmatic, postmodern postsecular thought appears somewhat inoculated from or immune to more embodied local discourses and contests of identity. This is why an important aspect of the question is that of the institution of knowledge, of the academy in its identity-forming role. For there is no doubt, for me at least, that identity-formation-who one becomes, the kind of subjectivity one develops-is, of necessity, influenced, if not shaped, by one's education, one's bed-side reading companions, one's cultural inheritance.

In what follows, then, I will consider ways in which we, as subjectivities within the academy, have been transformed by a more inclusive academy, and whether or not such transformation is even possible. For this reason, I begin with an analysis from Latin feminist philosopher, Ofelia Schutte, of the impact of postcolonial subjectivity on Continental thought. I'll then turn to J. Kameron Carter's analysis of the same in our, as Western subjectivities, filmic imaginary. For both thinkers, the prognosis is not optimistic: we seem to be unable to change and the others seem to be so readily coopted. Hybrids, that is, are just another iteration of the melting pot identity.

My answer to these analyses, the answer of this secular theology of language, does not challenge them, but makes possible, instead, another way to envision change within the hegemony of the academy, within our world-culture that is, for us, all that is the case. As I have already intimated, this way invites us to re-think subjectivity and subject-formation as a material process, and I am indebted to Malabou's own materialist ontology precisely insofar as her thought affords a strong reading of deconstruction, one, however, that makes ontology relevant again. The secular theological dimension of this formation is desire, a desireto-no-end. ${ }^{7}$ And the rebellious no! is how we rebel against even the structural walls that have a monopoly on our world-order. ${ }^{8}$ $W e$, in our double-consciousness, in our differences, in our instability, through our becoming and in spite of our imperfections, we, like a knight of faith, may not be able to speak clearly in ways that defy our cultural inheritance, but in our being-its plasticity-we do say no!

Schutte, in her attempt to analyze how postcolonial critique, as the disruptive insertion of postcolonial subjectivity within European discourse, is 'felt in Continental thought,' has referred to the 'resonance factor' of postcolonial subjectivity in Continental philosophy' (Schutte, 2003). In my view, her effort is indicative of a struggle not to let a hybrid conception of subjectivity fall entirely prey to a charge of complicity with the liberal master narrative. Finding herself with one foot in a dominant discourse as 'its' Other the hybrid subject is for that reason no longer silenced, and for that reason then, silences those who are 'truly' Other, like the subaltern of whom Spivak writes that she 'cannot speak' and those who, beyond the point of abjection in a Butlerian sense, are-besides unthinkable in virtue of forming the normative subject's constitutive outside, more to the point-unspoken. 'The subaltern cannot speak' is Spivak's answer to the 'danger of appropriating the other by assimilation' (Spivak, 1988, p. 308).

Not surprisingly, since, as Schutte suggests, 'postcolonial subjectivity points to the [subjective] incompleteness of Eurocentrism, not just its blindness or its arrogance.' Its point of insertion into the dominant discourse is marked by two trends that betray, besides or alongside the coloniality of the latter's power, how this coloniality works to fold in what threatens the hegemony of the
Western subject-to fold in postcolonial subjectivity (Schutte, 2003, p. 159). Before we return to the 'resonance factor' and how I understand this issue as pertinent to the question at hand concerning the eclipse of women, gender, and differences in postsecular theological discourse, I want to look at the two trends in Western thought from a postcolonial studies' standpoint, namely, the peripheral inclusion of minority discourses within the academy and the exportation of Western ideology through colonial/ postcolonial subjects. ${ }^{9}$

For the first trend, the insertion of postcolonial subjectivities coincides with the explosion of the notion of canon and with the 'diaspora of philosophical ideas' outside of the disciplinary perimeter of Continental philosophy 'proper' (Schutte, 2003, p. 157). It is easy enough to remind ourselves of the French-Algerian roots of Derrida and Cixous' JewGreekness. At the same time, in the United States at least, academic philosophy becomes so parochial that even Continental philosophy is all but expunged from it. One might need to venture into the religion department to read Heidegger or Deleuze. Likewise, one might also need to venture outside of the seminary and into the aforementioned religion department to think theology after the death of God. The point is simply that inclusion (of the dominant discourse's 'own' other voices) is conditional. One could say also that these critical voices on the weak side of the Western logocentric binary are excluded in their eccentric, peripheral, inclusion. And thus, that is precisely how they are included-how they are folded into the dominant discourse. Or again, the Western subject remains unaffected: it deflects the critique that opens it up to its own vulnerability by creating another space, where all 'its' critical voices can sing to their own choir without so much as causing a ripple in a dominant discourse that has barricaded itself into a bunker, with border patrols, fences, strict immigration policies, and so forth (but really, and most efficiently under the guise of its democratization.) The point to take away is that the conditional inclusion of the others turns their hybridization (one foot in, one foot out) into a buffer zone for the Western subject.

In this first trend, the blurring of disciplinary lines that puts the Western subject in question happens on the margins of a major discourse in which the Western subject remains whole and impervious, if not in philosophy, then in the becoming scientific of philosophy and psychology-for instance, or more generally, in what's dubbed the corporatization of education. Today's graduating senior must be equipped to face the problems of a globalized world order. She must be able to solve problems-obstacles in the way of the globalization of capital, so that she may be employable herself. And it is to this end that she must develop intercultural awareness. In other words, higher education becomes job training, even-or perhaps even especially-under the guise of intercultural competence. By this perverted logic, to become educated is to become adjusted to a maladjusted world.

The second trend refers to a certain diaspora: a diaspora in name only, it would appear. That is, a Western appropriation of an 'intelligentsia from developing countries' under the guise of a 'new diaspora' whose embrace of the postcolonial project is compromised by its assimilation of Western ideology (for instance, one might imagine how its critique of the impact of colonization assumes the historical realization of modernity as exemplified by the West, that is, through secularization and starting with the Enlightenment (Schutte, 2003, p. 160). In contrast, a decolonial perspective would, to be sure, correct the timeline and identify 1492 as the beginning of Western colonization. In addition, the postcolonial project is an academic project, so in this sense, it belongs to the West) The second trend further guarantees the erosion of the eccentric disciplines' critical edge in nudging the Western subject off kilter by creating an 'elite postcolonialism' (Spivak's term as cited by Schutte, 2003, p. 161). The idea is, borrowing from Spivak's 
Postcolonial Reason, that the colonial subjects as the counterparts to the Western subject become the 'postcolonial informants' of a 'benevolent third-worldist cultural studies impulse' in the US academy (Spivak, 1999, p. 360). The postcolonial informants, 'complicit' as 'folded into' the Western knowledge producing structure, can only imagine in their identification with the oppressed, 'at best,' according to Spivak, a third world cultural narrative that bespeaks a desire for nation building or recollects a previous cultural, historical sense of identity (Ibid.). But, 'at worst,' the postcolonial informant touts the upward mobility of the postcolonial 'as resistance' (Ibid.). In sum, such narratives squelch, or relegate to the 'penumbra,' the 'racial underclass' or the 'subaltern South' (Ibid., p. 361). In other words, the postcolonial dialogue in the academy, and to speak in terms of a color line language reminiscent of the critique from the critical race theorist George Yancy, creates a whitening of the Globe either meant to ensure the erasure of, or that 'undermines the struggle' of, the racial underclass that underwrites the capitalist project (Spivak, 1999, p. 360; Yancy, 2012). ${ }^{10}$ Here, any language of the Other, as a writing in the margins of the dominant One, is complicit in this scheme, and in fact redoubles-ensures the perdurance of the drowning, erasing, silencing of the subaltern and racial underclass. Quoting Spivak again: 'colonialism was modernization/ism:: postcolonialism is resistance to postmodernism; or, the 'true' postmodernism; now, only the postmodern postcolonialist is the triumphalist self-declared hybrid' (Spivak, 1999, p. 361). To extrapolate on this last formulation: one imagines a postcolonial subject, who fully abreast of postmodern and postcolonial critiques, is now at home in this view, knowledge and struggle, and for this reason has become tone deaf to those whom these critiques erase: those outside of this global knowledge and this global academy.

After pointing this out herself, Schutte adds that 'affirming a hybrid perspective on postcolonial subjectivity is a healthier practice than is that of trying to establish oneself as a selfnominated official reader of European texts from the so-called periphery' (Schutte, 2003, p. 160). Indeed, the question might be felt as one of integrity. If you pass for what you are not (a French philosopher, for instance), you are not what you think you are (an Algerian born GreekJew).

By this reading, postcolonial thought reveals the "true" (or is it the co-opted?) colors of the postmodern JewGreeks: their hybrid subjectivities in the service of a benevolent global West to come. And it seems we might lodge a similar critique against postsecular theological discourses.

Carter (2014), in a public speech entitled 'Postracial Blues' given to an undergraduate audience in spring 2014, offered a similar analysis of the 'resonance factor' of postcolonial subjectivity as it appears in our contemporary filmic Western imaginary. Carter points out that in the movie Avatar, the Western subject's solution to its problem of the other is to clone this other's body, but this in order to inhabit it spiritually. Hybridity serves the Male Western subject as he passes for the feminized, primitive other, while remaining oneself within. This covert hybridization of the other results in its appropriation for the Western project of maintaining the privileged status of the white, male subject. He is now blue. But on the inside, he has not changed an iota. More to the point, he is now poised to colonize the other blue people's minds. Here then, even in the imaginary, the project of decolonization fails as the white, male ego remains unscathed under his new colors, as the common world envisaged returns his humanity unscathed to the prideful Western subject. This new conquest is soft and gentle, and he gets to save 'his' world-he gets to preempt, to further erase from his memory, the genocidal racism that he first engendered.

District 9 is the other movie that Carter analyzed for comparison. In this film, alien prawns-giant prawn-like machines- are stranded on earth and secluded in internment camps bordering Johannesburg. They are 'harmless,' but they contain or all their machinery contains a special fluid that, we come to learn, is 'infectious' to humans, as an Afrikaner bureaucrat in charge of the relocation of the prawns, gradually and agonizingly, metamorphoses into one of them. His becoming monstrous vilifies him, save to the audience who becomes ever so attuned to the 'humanity' of the prawns. But in the end, the only possible solution to this baleful encounter is a clean break. A prawn named 'Christopher' uses the recuperated fluid to return to his mothership, while the other prawns are firmly secured in their new district. The bureaucrat, one presumes, is now an alien on the lam. No common world and no hybrid form of life is imagined or imaginable. We surmise that Christopher will eventually rescue the prawns from humanity and lead them back home, and that when he does, he will bring with him some cure to return the morphed bureaucrat to his human form. For one fails to imagine the possibility of a complete transformation-a transcendenceof man into a robotic life-form with a chitin-like exoskeleton. Man, we must assume, remains trapped.

Thus, at least in this film, hybridization is not an excuse for Westernization and globalization. However much we may sympathize with these alien creatures, they are different-even in their, what shall we call it, their humanity? But alas, that would negate their difference. We cannot recognize in them what is alike in us, unless perhaps in the name of pantheism. And then, we still commit yet another anthropomorphic rapprochement. God is all things and, of course, since we humans too are God-that is, God is just a projection of man writ large-we too are all things. And since we is not she or any other gender, this pantheism à la Feuerbach is revealed as just another Western humanism. So that if the task of the modern era was the 'realization and humanization of God-the transformation and dissolution of theology into anthropology,' as Ludwig Feuerbach so lucidly put it, the task of the postmodern era would be the realization and hybridization of Man-the transformation and the dissolution of anthropology into the pluralistic logic of the White Male Subject, the logic of the two (or the many) in one, the totalization of difference (Feuerbach, 1986: para 1). But what, then, of the task of the postsecular era?

\section{Part II. The postsecular}

First, in a manner all too reminiscent of the logic exemplified in those classical arguments for God's existence, where, for instance, God's existence is shown to be necessary, or where the nature of the universe as created in time or as co-eternal with God is reasoned through, or again, where infinite regress and the possibility of nothingness force reason to accept that nothing exists without a first cause, the postsecular era must defy historicization: it has either always already existed or it will never happen.

As we know, the meeting of Athens and Jerusalem is characterized in the West as the point of inception of the debate between faith and reason whose culmination in the Age of Enlightenment opens the door to the Weberian secularization thesis. In this scenario, the postsecular is also dubbed the return of the religious. But does it return as the same? And if it doesn't, then how does 'it' return at all? How does it fare in its confrontation with an other, with the infinity of the Otherness of the other? Is the postsecular thinker, the postsecular theologian, a real material being in space and time, a different subject?

As we have just seen, whether in the academy or at the movies, the postmodern/postcolonial scenarios recalled above all seem strikingly similar: the hybrid figure does not lead to a real change of 
world order. Either the colonial subject who aspired to be a modern European to free her country from colonial oppression becomes a hybrid postcolonial subject (who, in having a marginal place, silences the real others and advances the big o's modernizing humanitarian project.) Or, the exotic other is no other at all in the end, as the One inhabits its mind, all sin expunged from its memory. Or, the monstrous other is irreparably other because of our damned Westernized imagination to which we, together with the she and the other ones that belong to the One, are doomed.

But, between totality and infinity is there really no real difference at all? As Walter Mignolo points out, already in the seventies, Enrique Dussel made the case to Emmanuel Levinas that although their projects aligned, Levinas' Other was Eurocentric. Levinas' candid answer to Dussel was that 'he never had thought that the "Other" could be the "indigenous peoples, Africans, or even Asians"' (as quoted in Mignolo, 2003, p. 84). Thus Dussel to add, 'The Other of the totality of the European world were all the cultures and humans which had been constituted as things ready at hand, instruments, known ideas, entities at the disposal of the 'European (and later Russian-North American) will to power' (Ibid., p. 84).

Second, there is more than one way though to argue that there can be a real difference between totality and infinity, and that the postsecular has always existed. One way is still, ironically, through the prism of language, as Jacques Derrida had argued, for instance, against Michel Foucault that the advent of the modern rational subject exclusive of madness was not as much a classical invention as it represented an example of the 'origin of history,' as 'historicity itself, the condition of meaning and of language' (Derrida, 1978, p. 42). As if Derrida were suggesting that, 'if the structure of exclusion is the fundamental structure of historicity,' this means that the modern Cartesian subject (and we may add, the Eurocentric, heteronormative, white male subject) isn't the first or the last to exclude its irrational other (the madmen Descartes is quick to distance himself from in his Meditations, women, savages, etc...). That is, every mode of inscription historicizes what it inscribes by excluding what it omits, even when it includes what it includes in between the lines or by its conspicuous omission, allusion or denial. The postsecular, in this view, tends to take the historical concreteness of the advent of the hybridization of Western Man with a grain of salt. Perhaps in a historically postmodern view, the crisis of universals leaves us all in erring, à la Mark C. Taylor, de-centered and ungrounded. But, for those discourses of the return, for the postsecular, this historical crisis is perhaps instead a universal condition. Here is one more way, it thinks, that historicity asserts itself. This is not the end of history, nor the end of the book, nor the end of the author. And so in this view, the subject of history need not be the Western subject or the white male or the Christian God. But it will exclude, even in its postmodern gesture of inclusiveness. At the same time, consistent with a Derridean ethic, this subject will also always be deconstructible; it will always include within itself as its ground, its point of departure, what it purports to exclude, its difference. ${ }^{11}$ And God, here, is other to this other: unforeseeable to come, messianic, a promise that besides all our known unknowns, there is more. ${ }^{12}$

Let's pause on the very assumption that, to repeat, every mode of inscription historicizes what it inscribes by excluding what it omits, even when it includes what it includes in between the lines or by its conspicuous omission, allusion or denial. Let's pause on this very claim that historicity itself is the condition of meaning and of language. This claim would be congruent with Western metaphysics which sets the very limits of logic and discursivity in the first place, which, from the outset, posits the conditions of knowing and sense within a linear temporality, a spatial time-we move forward, we look back - and which, finally, marginalizes as esoteric, feminine, or irrational any ways of knowing not consciously reasoned through as per a Western epistemology. Différance includes onto-theology and exceeds it, but even Derrida never claimed to have escaped (Western) metaphysics. Or, as Robert Bernasconi contends, 'insofar as Western metaphysics has from the outset been deconstruction's primary object, deconstruction has had little use for what falls outside of Western metaphysics' (As quoted in Mignolo, 2003, p. 84). It is at this point that we begin to feel how provincial we have been, and the provincial origins of our universalist ambitions. ${ }^{13}$ But then, is there really no way out of this anthropomorphic solipsism, must Spivak have the last word?

I would like to think not. Instead, we can and ought to consider what Mignolo has coined 'border thinking' and 'border gnosis/ gnoseology' as a genuine alternative to Spivak's position that 'the subaltern cannot speak' or that we cannot but 'appropriate the other by assimilation' (Mignolo, 2003). Mignolo is an Argentine thinker of Italian origin who is astutely aware of the coloniality of power and whose own identity and subjectivity are marked by this coloniality. In his own calling attention to this locus of enunciation, Mignolo contends, as he puts it, 'I am where I think' (Ibid.). In this view, the subaltern does speak because her point of reference is not that of modernity, postmodernity, and the West. Her point of reference is the decolonial which stands as another option, a pluriversal option of communalism beside the universal options of capitalism or communism. From his perspective, we are the problem for being deaf, or for hearing only what we know.

Still, the current charge is that the return to religion via postmodernism - the postsecular-is yet another instantiation of Western humanism, that the theorization of the linguistic turn legitimizes the status quo, or that this theorization is impotent, because, structurally, it remains Eurocentric and thus is complicit with or can be folded into hegemonic global capitalism. I want to return to this assumption concerning the hegemony of the Western subject. It seems that even if we kill him, he would survive his own death. In the same way that we have killed God, yet God is not dead.

I reiterate that a secular theology of language can resist this hegemonic logic from within, and that while deconstruction in its formidable critique of logocentrism can be seen to fail to instantiate real change, this is because the linguistic turn is essentialized. That is, it is Platonized in a post-Kantian fashion: language is the deformed form of the real, but not its noumenous matter, which remains unknowable. Thus, the hybridized other is (de)formed into the one, its otherness altogether disappeared-its matter made irrelevant or impotent for its being relegated to the realm of the noumena. It is not enough, though, to historicize the linguistic turn. When we do so, we end up with the failed attempts to go beyond the turn that are dubbed a return: we witness the return of religion that announces the failure of the secularization thesis on the one hand, and on the other, announces the kingdom of capitalism. Certainly, the Radical Orthodoxy movement comes to mind, or one might also think of Philip Goodchild's argument in his Capitalism and Religion (Goodchild, 2002). But also, and in short: we return to what is merely a universalized church, à la Altizer (Altizer, 1966), or Christian empire, à la Keller (Keller, 2005). Construed in this sense the postsecular, in historicizing the postmodern, has nothing to offer but the Western project. However, between essentializing our linguistic condition and historicizing it, or rather, at the crossroads, there are millions of becoming subjects. Our theorizations tend to forget and can only but abstract from the lived experiences of these becoming subjects. In their individuality, they all resist assimilation. In their irreducibility, death is their only predator. In their materiality, they limit discursivity. And, if in in their instability, they inscribe their invisibility, that is because, in language, they rebel against logocentrism. 
Is there a real difference between these millions of becoming subjects and that of the postcolonial informant who declares that upward mobility is a form of resistance? An insurrectionist theology of language cannot rule out the possibility that upward mobility is a form of resistance. It certainly can be felt as such, as a bras d'honneur, defiance in the face of double consciousness and the oppressor's gaze: the point at which the problem of the other becomes the one's own problem of self-validation, the resonance factor that reveals to the Western subject that his biggest threat is a 'loss of individuation' in his confrontation with an "Other vision" or an 'Other language' in an other subject who now speaks his language as well while he remains monolingual through and through. But be that as it may, how is this upwardly mobile or assimilated subject not coopted by the logic she wants to defy? It is true that just as we can think of the USA as the bigger and better version of Europe's Utopic vision of itself, and thus we can think of the USA as an even more monstrous realization of the Western subject than its model exemplar, we can stereotype the postcolonial subject, in her hybridity, as an informant in the service of the West, as a 'bigger and better' version of the Western subject. By extension, we can assume that a secular theology of language, in recovering the religious, risks in its own kind of hybridity the collusion of the religious with a dominant discourse in the guise of its liberation from that discourse. At the same time, what this dark picture forgets is that the order of things is also and always, besides a historical, a material order. Let the noumenal realm recede ad infinitum, let it be, in its objectification, yet another deformation or a misperception of the knowing subject, this materiality makes its way into our ways of thinking even when we repress it. This is a lived materiality, not an unintelligible empty concept-a materiality that is worded just as it too words the world. A secular theology of language hopes to change the vision-a tunnel vision-of the double bind of the other-in her postcolonial difference, in her bitch difference, in her imitative difference, in her veiled difference. The perspective is skewed. Air needs to find its way back into that airtight Leviathan-like totalizing vision of infinity. Echoing Malabou, a change of difference is what is needed.

But what exactly is a change of difference? If, after Derrida, 'writing' is, as Malabou writes, the new 'motor scheme' of an epoch $^{14}$ such that there is no speech that is not always already understood to be a 'writing' (Malabou, 2010, pp. 12-17). This motor scheme has run its course, as it is now apparent from the preceeding analyses that the very limitations set up by the motor scheme of writing concern precisely the production of difference -always the same difference ${ }^{15}$ But what is forgotten in this epistemo-linguistico-phenomenal setup of an ontological abyss (the constitutive others of the same one, and besides them, the unthinkable, subaltern, abject others) is that writing belongs to materiality. This is a radical materiality where, as expounded in Malabou's The Heidegger Change, being differs with itself and is change (the change without which writing becomes an alienating trope that totalizes difference.) When being differs with itself, writing remains within being. Thus, in this way, the question of opening difference to differences, opening the other to others, of making a difference in this dizzying, infinite, tumble down the same rabbit hole goes beyond the straightjacket of the binary from which it stems. For instance, in Changing Difference, Malabou's plastic ontology implies that femininity no longer stands opposed to masculinity as the latter's other, or confined and defined by heterosexual patriarchy and thus both without meaning on its own and signifying no more the second sex than all the others (the marginalized, the poor, minorities, etc...). Instead, femininity owes to women everywhere its 'empty but resistant essence, an essence that is resistant precisely because it is emptied, a stamp of impossibility' (Malabou, 2011, p. 99). This positivity belongs to the materiality of being and because being is change, and writing therefore remains within being, this positivity transvalues the difference; it can transform the symbolic orderby resisting it. Likewise, being no longer stands outside of the machine, a dead ghost of metaphysics that haunts the most secularist discourses, or opposed to becoming, and constitutionally warding off differences. Instead, being is change, transformability, hope in living-in expenditure.

Is this not the hope that we hear in the words of W. E. B. Du Bois when he writes that 'The history of the American Negro is the history of this strife [of two unreconciled strivings; two warring ideals in one dark body striving], - this longing to merge his double self into a better and truer self...' where '[h]e would not Africanize America... He would not bleach his Negro soul... He simply wishes to make it possible for a man to be both a Negro and an American, without being cursed and spit upon by his fellows' (Du Bois, 1994, pp. 2-3). Isn't Du Bois' gesture towards [a kind of?] transcendence, his longing to attain a 'better truer self - stemming, as it does, from a lived embodied experience of double-consciousness-a form of resistance? Is this not a rebellious no! to the logic of the two in one-the two that must become one as either wholly Africanized or entirely bleached? Is there not in this vision of a better truer self, a truly changed being whose possibility bespeaks of a being that is change itself?

Here, the being that is change is the being of a lived materiality that is invested in our conceptual order so that to change the vision of the double bind of the other, we must recover the materiality of concepts, and we must keep from anthropomorphizing this materiality: not that a word corresponds to a real material thing, but that a word has flesh, and matters. ${ }^{16}$ There may be nothing outside of language, but language is alive. Words are felt, words are investments, words are instruments of change, words are not only made flesh; they are also made of flesh and empty otherwise.

We might turn to object-oriented ontology for that. And yet, here too, otherness in remaining other also objectivizes the One, alongside its Others, and is also exceeded by others beyond one's Western imagination. And it also objectivizes the hybrids, such that the net of the One simply can no longer be cast wholly over them. They are not just 'post-colonial informants' or White women, or recognized minorities both silenced in their being recognized and silencing those who really have no voice at all. This, then, might be a step in the right direction, though it still smacks of a kind of exotic orientalism, as a studying of the other without a philosophical decision articulating a privileged subject position called the human. I think that a decolonial perspective would take issue with this wholesale pigeonholing of human perception and would urge us to recognize, to learn to unlearn how we are thinking this human and her ways of knowing as a necessity of her essence rather than of her Western condition as universal subject. Perhaps an amended version or decolonial version of an object-oriented ontology would affirm the reality of objects as 'thinking others' outside of Western perception and echo Mignolo's answer 'Yes, we can!' to Hamid Dabashi's question in his eponymous book, Can Non-Europeans Think? (Dabashi, 2015). Now, if only Europeans could read. That is, if only we could appreciate without appropriating, if only we could encounter without assimilating-if only we would.

For those of us within the Christologocentric prism, it is clear at this point that we can't simply step outside, rewind, or disentangle ourselves from the structural sins of whiteness and colonialism. It is undeniable that Mignolo's 'I am where I think' comes before Descartes' 'I think, therefore I am,' that is, that there is no epistemology independent of a locus of enunciation. And a postsecular return of religion must also return the gift of privilege -not to be confused with denial, forgetting, or absolution. By 
'return' then, I mean a transformative return of the subject-a rebellious no!

I am reminded of Risieri Frondizi's efforts to explain the self over against both the atomists and the substantialists, the Humes and the Descartes, as neither positions could explain the full spectrum of the experiences of the self: a self who can misrecognize herself; who can transform or be transformed by events, and still make sense of herself without contradiction-or not. He called it the structural dynamism of the self. But what we have here is a subjectivity under erasure; a subject in process on trial, a subject superject. Some to say: just another co-opted hybrid. But an insurrectionist theologian to turn back to them and say: Look, a human being.

Received: 25 May 2018 Accepted: 30 October 2018

Published online: 27 November 2018

\section{Notes}

1 Whom does this 'our' refer to? To western-trained academics, and also to westerners, first-world peoples, and so-called modern language speakers. This 'our' makes no claim beyond this appurtenance of our respective identities, namely, a hegemonic discourse and order. But, in a stricter sense, this 'our' also refers to postsecular thinkers.

2 In this way, I am evoking and building on the argument on behalf of a secular theology of language from Vahanian (2014).

3 For more on insurrectionist theology, see Blanton et al. (2016)

4 For instance, see Caputo et al. (2007).

5 For such a critique, see Hägglund (2008)

6 One could say that no universal human being-as-such exists, in the same way that no universal triangle exists. But unlike with triangles, the dominant universal conception of the human being hides-besides the human 'enigma' as such-the geo-political history tainting the anthropomorphic bias at the heart of the concept. Beyond its dictionary definition, the dominant concept 'human being' also conjures the superiority and control of the human over the animal, whether through speech, reason, tool-making, the idea of God, and so forth. This human-all-too-human anthropomorphic bias, in turn, is not neutral either. It reflects a Western, patriarchal bias, inasmuch as this imagined human being evokes the cosmopolitan ideal of the modern subject: in its abstraction, an objective and scientific concept or an autonomous individual; in practice, a Western, heterosexual male. My term, "earth animals," only wishes to emphasize this tension in what we may otherwise aptly term our human-all-too-human perspectivalism.

7 For the concept of a desire-to-no-end, see Vahanian (2003)

8 See footnote 1 for my use of we.

9 Schutte identifies these trends in her article. I am extrapolating from these in what follows.

10 For his development of the concept of the color line, see Yancy (2012).

11 See for instance Critchley (2014)

12 See Caputo (1997).

13 For my use of the term 'provincial,' see Chakrabarti (2000).

14 On this very concept of the 'motor scheme,' see Malabou (2010). In particular, in referring to Derrida, Malabou writes that, 'for example, the act of conferring an enlarged meaning on writing has nothing at all to do with an arbitrary decision or 'word play.' All thought needs a scheme, that is, a motive, produced by a rational imagination, enabling it to force open the door to an epoch and open up exegetical perspectives suited to it' (Ibid., 13). Or again, of this new meaning of writing: 'it is also an invention born of a productive philosophical imagination' (Malabou, 2011, p. $54)$.

15 This is not a dismissive critique of the deconstructive position, but it is, instead, an attempt to think through or beyond the loss of the real or the groundlessness of being, or more to the point, to think the materialization of a subjectivity whose material historicity is not predicated on an exclusion-the constitutive outside. This is an attempt to think, to take stock of, real becoming subjects as opposed to self-same rational subjects who think and therefore exist, or to 'others' who don't 'really think' and whose existence is therefore conditional on the subjects who think them.

16 I don't mean that concepts have unchanging referents to which they point or that concepts are things. I mean that concepts are not born of nothing, but of a lived experience; they can be felt, or sensed even if they cannot be held in one's hand.

\section{References}

Altizer T (1966) The gospel of Christian atheism. Westminster Press, Philadelphia
Blanton W, Crockett C, Robbins J, Vahanian N (2016) An insurrectionist manifesto: four new gospels for a radical politics. Columbia University Press, New York, NY

Caputo J (1997) The prayers and tears of Jacques Derrida: Religion without religion. Indiana University Press, Bloomington

Caputo J, Vattimo G, Robbins J (eds) (2007) After the death of God. Columbia University Press, New York

Carter J (2014) Postracial blues. In: Undergraduate Symposium on a living philosopher lecture series, Lebanon Valley College, Annville, PA

Chakrabarti D (2000) Provincializing Europe: postcolonial thought and historical difference. Princeton University Press, Princeton

Cox H (1965) The Secular City. Macmillan, New York, NY

Critchley S (2014) The ethics of deconstruction. Edinburgh University Press, Edinburgh

Dabashi H (2015) Can non-Europeans think. Zed Books Ltd, London

Derrida J (1978) Cogito and the history of madness. Writing and difference. University of Chicago Press, Chicago

Du Bois WEB (1994) The souls of black folk. Dover Publications, New York, NY

Feuerbach L (1986) Principles of the philosophy of the future. Hackett Publishing Company, Indianapolis

Goodchild P (2002) Capitalism and religion: the price of Piety. Routledge, London

Hägglund M (2008) Radical atheism: Derrida and the time of life. Stanford University Press, Stanford University Press

Harman G (2014) Objects and orientalism. In: Xie M (ed) The agon of interpretations: toward a critical intercultural hermeneutics. University of Toronto Press, Toronto

Keller C (2005) God and power: counter-apocalyptic journeys. Fortress Press, Minneapolis

Malabou C (2010) Plasticity at the dusk of writing: Dialectic, destruction, deconstruction. Columbia University Press, New York, NY

Malabou C (2011) Changing difference: the feminine and the question of philosophy. Polity Press, Malden

Mignolo W (2003) The colonial difference. In: Mendieta E (ed) Latin American philosophy: currents, issues, debates. Indiana University Press, Bloomington \& Indianapolis, p 88-86

Schutte O (2003) Continental philosophy and postcolonial subjects. In: Mendieta E (ed) Latin American philosophy: currents, issues, debates. Indiana University Press, Bloomington \& Indianapolis, p 150-162

Spivak G (1988) Can the subaltern speak? In: Nelson C, Grossberg L (eds) Marxism and the interpretation of culture. University of Illinois Press, Urbana, p $271-313$

Spivak G (1999) A critique of postcolonial reason: toward a history of the vanishing present. Harvard University Press, Cambridge

Vahanian G (1961) The death of god: The culture of our post-christian era. George Braziller, New York, NY

Vahanian N (2003) Language, desire, and theology: A genealogy of the will to speak. Routledge, London and New York, NY

Vahanian N (2014) The rebellious no: variations on a secular theology of language. Fordham University Press, New York, NY

Vattimo G (2002) After Christianity. Columbia University Press, New York, NY

Yancy G (2012) Look a White! Philosophical essays on whiteness. Temple University Press, Philadelphia

\section{Additional information}

Competing interests: The author declares no competing interests.

Reprints and permission information is available online at http://www.nature.com/ reprints

Publisher's note: Springer Nature remains neutral with regard to jurisdictional claims in published maps and institutional affiliations.

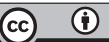

Open Access This article is licensed under a Creative Commons Attribution 4.0 International License, which permits use, sharing, adaptation, distribution and reproduction in any medium or format, as long as you give appropriate credit to the original author(s) and the source, provide a link to the Creative Commons license, and indicate if changes were made. The images or other third party material in this article are included in the article's Creative Commons license, unless indicated otherwise in a credit line to the material. If material is not included in the article's Creative Commons license and your intended use is not permitted by statutory regulation or exceeds the permitted use, you will need to obtain permission directly from the copyright holder. To view a copy of this license, visit http://creativecommons.org/ licenses/by/4.0/. 